\title{
Protecting Copyrights and Related Rights in the Digital Dilemma: Some Challenges
}

\author{
B.A.R.R Ariyaratna \\ the Department of Legal Studies of the Open University of Sri Lanka \\ ruwanthika.ariyaratna@gmail.com
}

\section{W.A. Sanath Sameera Wijesinghe}

PhD Candidate, Faculty of Law, School of Law, Queensland University of

Technology, Brisbane, Australia and a Lecturer in Law at the Department of Legal

Studies of the Open University of Sri Lanka. sanathwijesinghe@gmail.com, sanath.arachchilage@hdr.qut.edu.au

\begin{abstract}
Intellectual Property plays a vital role in modern economies as a valuable intangible asset. Particularly, copyrights and related rights can be considered as a one of the most viable intellectual property rights which can easily be acquired as well as unduly exploited. Notably, the violation of the legitimate rights of the copyright owners has been gradually increased with the proliferation of modern technologies. It is evident that it is easier to make unauthorized copies of copyrighted works with using technologically advanced equipment within mini seconds without consuming much effort. Inevitably, such a misappropriation of property rights would challenge the interests of the owners who devoted their skills, interests and labour to create that work with a financial motive. Therefore, the existing intellectual property law is being modified in order to cater the new challenges on copyrights which occur due to the expanding nature of digital environment. The primary objective of this paper is to identify and anlyse the changing nature of the challenges on copyrights and related rights in an era of digitalization. Also, it aims to analyse the recent developments of international law for the purpose of gaining better understanding of how and to what extent these issues have been identified and addressed in international level. Furthermore, it discusses the experience of some selected jurisdictions such as Unites States, United Kingdom and European Union, in order to make out some recent trends in protecting copyrights and related rights in a digital environment. Finally, this research intends to identify the loopholes of Sri Lankan law and propose some suggestions to enrich existing law relating to copyrights and related rights so as to strike a balance between the rights of the owners and general public.
\end{abstract}

Keywords: intellectual property, copyrights, related rights, digital environment, striking a balance

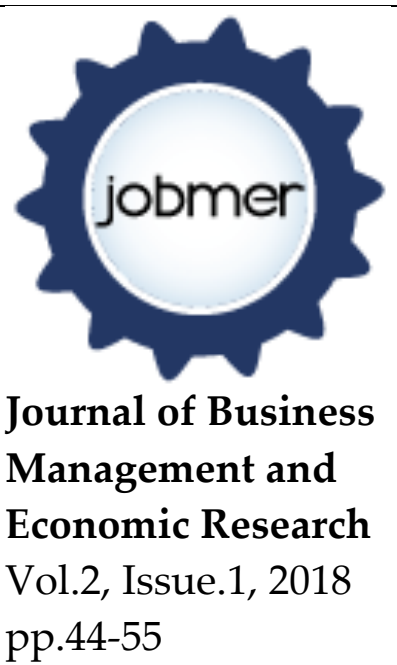

Doi: 10.29226/TR1001.2018.20 


\section{Introduction}

"Digitization has made it much easier to manipulate, reproduce, and distribute protected works. Digital content can be combined, altered, mixed, and manipulated easily. By enabling the making of perfect copies of copyrighted works for little cost, digital technology threatens to undermine the distribution systems and increase unauthorized use of copyright works..." (Rafiqi and Bhat, 2013)

Copyright can be recognized as an exclusive right of an author in relating to his or her creation. As Karunarathna (2010) pointed out, "the law of copyright concerns the rights of the authors of literary, artistic and scientific creations - commonly known as 'works'-and legitimate interests of the users of such creations." However, it is notable that, copyright law protects only the form of expression of ideas not the ideas themselves. (WIPO ,2008)

As recognized by Article 2 of the Berne convention of 1971, copyright protection includes diverse forms of creativity, such as, for example, writings, musical compositions, films, drawings, photography or architectural creations and etc. In addition to that, the WIPO Copyright Treaty of 1996 (WCT) introduced computer programmes, considered as literary works.

As well, there are related rights or neighboring rights attached to the copyright protection. It can be identified under three categories, the rights of performing artists in their performances, the rights of producers of phonograms in their phonograms, and the rights of broadcasting organizations in their radio and television programs (WIPO, 2008). These related rights protect the interests of the persons who contribute to develop the creation by expressing some kind of creativity or skills.

the proliferation of technology leads the copyrights and related rights regimes towards rapid changes which would be pervasive enough to cater to the needs of the 'creators' on the one hand, and society at large on the other. Whereas the ultimate aim of copyrights and related rights is to make a fair balance between the rights of those two parties. For the purpose of achieving a tradeoff between these conflicting interests, moral and economic rights and a specific time period for economical rights are defined by law. However, the scope, purpose and the applicability of the copyrights and related rights are being challenged by the digital environment. Thus, to overcome these various challenges put forward by the expanding nature of the modern technology, a need arises to expand the frontiers of copyrights and related rights and to renovate the existing legal framework relating to protect those rights in networked and digitalized environment.

In analyzing the international legal context of copyrights and related rights we can identify some initiatives which address this specific issue of protecting copyrights and related rights in a digital environment. However, the Sri Lankan context is still not in par with international legal regime and need to be revised with more developed legal principles.

Thus, this paper aims to discuss the effect of digitalization on the scope and enforcement of the copyrights and related rights. Secondly, it discusses the international legal framework and recent developments of the European Union (EU), United Kingdom (UK) and the United States of America's (USA) to gain a better understanding of digitalization and its effect on the copyrights and related rights. Thirdly, this paper focuses on the existing Sri Lankan legal framework and its capability of safeguarding the rights of the creators in a digital environment. 
Finally, it concludes with suggestions to enhance existing law relating to copyrights and related rights which can be suited into the digitalized future.

\section{Theoretical Framework}

Among most other theories related to Intellectual Property Rights (IPR), the economic theory and utilitarian theory are central to this discussion. The economic theory mandates the certain exploitation of inventions or creations by the owners. Accordingly, this theory justifies the copyright owner's right to have a limited monopoly over his or her intellectual creation. However, the ideology of utilitarian theory is useful in harmonizing conflicting interests in the interface of IPR. As Fisher (2001) argues, the first and most popular of the four employs the familiar utilitarian guideline that lawmakers' beacon when shaping property rights should be the maximization of net social welfare. Therefore, it is evident that, while economic theory tilted on protecting the interests of the copyright owners, utilitarian theory emphasizes of striking down a balance between the rights of owners as well as the general public. This paper is constructed on the rationales of above mentioned theories.

\section{Research Methodology}

This research is a normative research which primarily based on an extensive literature review. The research comparatively studies United States, European Union and United Kingdom jurisdictions of copyrights protection in digitalized environment. The purpose of selecting comparative methodology is to identify the recent developments in this field and discuss it's applicability into the Sri Lankan context.

As primary sources, international instruments, legislations and case law such as WIPO Copyright Treaty of 1996 and WIPO performances and Phonograms Treaty, Intellectual Property Act No 36 of 2003 in Sri Lanka and US Digital Millennium Copyright Act have been used in this research. Furthermore, journal articles, web resources and text books have been referred as secondary sources in order to enrich the research.

\section{Results and Discussions}

\section{Copyright and Related Rights}

As pointed out by the World Intellectual Property Organization (WIPO); 'copyright is the legal protection given to the creator of an original work'. (WIPO, 2008) Nonetheless, it can be described as 'an encouragement that takes the form of valuable or enforceable rights that motivate the production of literary and artistic works of lasting benefits to the world'. (Washington Co. v. Pearson, 1939) Thus, it is meant that copyright is the exclusive rights granted by law to the creator of an original work to do, authorize or prohibit certain acts in relation to such work.(http://www.cott.org.tt/). The most remarkable fact is that copyright protection does not require any kind of registration to be entitled to Intellectual Property (IP) protection.

Rights of a copyright owner can be basically divided into two phases; namely, economic rights and moral rights. Economic rights of a copyright owner encapsulates certain rights which can be exploited by the owners and gain economic advantages such as right to produce the work in various forms, public performance rights, right to broadcasting the work via radio, cable or satellite, right to translate/adaptation of work and right of distribution of that work. However, for the purpose of having a fair balance between the exclusive rights of the copyright owners' 
interests and the interests of the society, these bundles of exclusive rights are limited to a specific period of time.

Where moral rights are concerned, these rights are independent from economic rights and can be considered as paternity rights attributed to the particular creation. Thus, it is clear that the economic rights coupled with moral rights grant an owner of copyrights an exclusive control over his or her rights. However, as lucidly pointed out by many scholars, as well as in the Berne Convention, 'fair use' exemptions and other limitations such as limitations on reproduction rights etc. can be used to limit the authority of the copyright owners. When anlysing the Sri Lankan situation, it is clear that the domestic protection of copyrights also more or less equal to the international legal framework.

Related rights are another set of similar rights which protects the rights of performers, producers of sound recording and broadcasting organizations. Related rights also hold an important place in the realm of IP, as the rights of inter-mediators who assist authors to communicate their intellectual creations to the general public. (WIPO, 2008) Related rights are very much linked with copy rights and sometimes can be considered as a result of copyrightable creations.

Table 1: Relationship between Copyrights and Related Rights

\begin{tabular}{|l|l|}
\hline \multicolumn{1}{|c|}{ Copyrights } & \multicolumn{1}{c|}{ Related Rights } \\
\hline Composer & Musician \\
\hline Play writer & Actor \\
\hline Author/composer & Recording industry \\
\hline Author/composer & Performer/singer \\
\hline
\end{tabular}

The related rights owners are given a bundle of exclusive rights to use and enjoy his or her intellectual creations. However, related rights are also limited by virtue of 'fair use' and the duration of protection. As per the Article 14 of the International Convention for the Protection of Performers, Producers of Phonograms and Broadcasting Organizations of 1961 (Rome Convention), the term of the related rights protection is limited to a period of twenty years from the date of incorporation, fixation and broadcast.

The Sri Lankan IP Act embraces three categories of rights- the rights of performing artists, the rights of the producers of sound recordings, and the rights of and broadcasting organizations. Though, IP Act grants this protection to the related rights in Sri Lanka, it is not dealt with complexities in a digital environment. Therefore, it can be argued that performers, producers of sound recordings and broadcasting organizations' rights are vulnerable in the Sri Lankan context and the time has reached to explore the prospectus of widen the existing protection.

When considering the both contexts of copyrights and related rights it is very clear that the international law relating to these regimes are rather comprehensive and well established in their own territories. However, the question is whether these established principles are able to cater to all complexities that have arisen with networking and digitalization in the current context. Thus, we have to consider the challenges that have occurred in using, transmitting and storing copyrighted and related righted works in computers and digital networks. 


\section{Digitalization and challenges to copyright law.}

As some scholars correctly opined, the rapid evolution of digital technology, and in particular the internet, enables the copy of a song, article, movie, or photo to be made without permission and to be disseminated around the world through the click of a button. (Dimock and Punniyamoorthy,2006) Contrast to the analog system, digital systems could be able to record and transmit information in higher quality in less time and at higher speed (Fleischmann,1987). Therefore, it can be argued that, the foundation of traditional copyright law protection has been challenged significantly after introducing the digital technology.

There are two extremes of arguments which are relevant to the copyrights and related rights in a digitalized environment. On the one hand, the commentators argue that the copyrights has no place in the digital environment whereas traditional copyrights cause to curtail, access and disseminate of knowledge. (Copyright News, 2012) On the other hand, it connotes that copyrights are needed for greater public good because it gives the authors an incentive to create and it encourages the dissemination of knowledge (IFLA, 2001). This notion equally applies to the related rights issue as well. The second argument is rather realistic and should be upheld on the basis that in order to ensure correct distribution, reproduction and selling of intellectual capital need to be monitored to avoid piracy of creations even in a digital environment.

Admittedly, there are third parties who are making a lot of money by selling or distributing copyright works electronically (Copyright News,2012). Illegal downloads of movies, TV series and software which are sold at very low prices effects the relative rights of the legitimate right holders such as film exhibitors, broadcasting organizations, performing artists and etc.

Two three decades ago the physical copies of the books and other literary works were more popular in disseminating knowledge. However, today the trend is using technology in selling, reproduction or even having digital versions of books and other literary works. Nevertheless, online selling of these works would be based on the payments and other encrypted mechanisms; we can find the pdf versions of most of works in the internet which amounts to a violation of the economic rights of the authors of those works.

Furthermore, the collections of books, journals, articles, musical works and other similar works are found on digital libraries, online archives and repositories such as Google books, Open Library etc. However, the lawfulness of these activities still remain uncertain and digital archives are challenged on the basis of non-clearance of copyrights. Sometimes, the 'fair use' limitation would permit the digitization projects to have digital archives of copyright protected works. (Authors Guide Inc v. Google Inc., 2012). For an example, in Sri Lanka, it is very easy to find the unauthorized copies of software, even though those are protected as literary works. Furthermore, the availability of thousands of fine arts, paintings and photographs have paved the way for violation of the rights of the authors of those creations.

Another contentious issue is digital technology has made copyright enforcement difficult to achieve due to its cross territorial nature. In the online environment, works such as videos, recordings of musical performances, and texts can be posted anywhere in the world, retrieved from databases in foreign countries, or made available by online service providers to subscribers located throughout the globe (Rafiqi and Bhat, 2013). So the issue is, how and whose law should determine whether the reproduction of protected work constitute infringement? 
B.A.R.R Ariyaratna, W.A. Sanath Sameera Wijesinghe, 2018, Vol.2, Issue.2, pp.44-55

Accordingly, it can be argued that, modern digitalization has challenged the existence, scope and protection of the rights of owners of copyright and related rights by making the tasks of the traditional copyright law more difficult and complicated. Therefore, it is obvious that, copyright law should be able to strike a balance between copyright holder's rights and millions of user's rights in the digital environment. Some mechanisms have been introduced in international and domestic jurisdictions particularly addressing this issue.

\section{World Intellectual Property Organization treaties, 1996}

World Intellectual Property Organization (WIPO) has introduced separate legal framework for addressing this contentious issues in digital environment. The WIPO Copyright Treaty (WCT) and the WIPO performances and Phonograms Treaty (WPPT) provide for a Berne-consistent update of the international copyright regime. (IFLA, 2001).

According to the Agreed Statement to Article 10 of the WCT, signatory nations are allowed to extend exceptions in the digital environment.

"It is understood that the provisions of Article 10 permit contracting parties to carry forward and appropriately extend into the digital environment limitations and exceptions in their national laws, which have been considered acceptable under the Berne Convention. Similarly, these provisions should be understood to permit contracting parties to device new exceptions and limitations that are appropriate in the digital network environment."

As mentioned earlier, the international consensus on providing better protection to copyrights and relate rights are primarily encapsulated in the WCT and WPPT. The preamble to the WTC connotes that the main objective of implementing this convention is to introduce new international rules and clarify the interpretation of certain existing rules in order to provide adequate solutions to the questions raised by new economic, social, cultural and technological developments. On the other hand, the WPPT is also designed to facilitate related rights in a very smooth manner which upholds the interests of both creators and general public in a digital environment.

When analyzing WCT and WPPT very closely, the both treaties incorporates the 'three-step-test' and further mandates members to devise new exceptions and limitations appropriate for the digital environment. Thus, it can be admitted that the WCT and WPPT have the effect of expanding the canvas of Berne Convention. Nonetheless, the courts also look into the matters relating to copyrights and related rights infringement in a lucrative manner well suited to have a tradeoff between the rights of the authors, as well as general public in modern context.

Nonetheless, Article 11 of the WTC provides;

Contracting Parties shall provide adequate legal protection and effective legal remedies against the circumvention of effective technological measures that are used by authors in connection with the exercise of their rights under this Treaty or the Berne Convention and that restrict acts, in respect of their works, which are not authorized by the authors concerned or permitted by law.

Similarly, Article 7 and 11 of the WPPT provide protection of reproduction rights enjoyed by performers and phonogram producers respectively. As it is stipulated in the agreed statement, the Article 9 of the Berne Convention shall apply mutatis mutandis to the protection of reproduction rights in the digital environment. 
B.A.R.R Ariyaratna, W.A. Sanath Sameera Wijesinghe, 2018, Vol.2, Issue.2, pp.44-55

Accordingly, it is evident that, both WCT and WPPT permit contracting parties to adapt suitable exceptions to protect copyright holder's rights in digital environment. Most of the developed nations have implemented WIPO treaties very progressively by enacting enabling legislations. The US Digital Millennium Copyright Act is considered as the most well-known and controversial implementation of the WIPO Treaties (IFLA, 2001).

\section{United States and European Union law.}

As mentioned earlier, the US Digital Millennium Copyright Act (DMCA) incorporated the WIPO law by specifically providing protection for copyright holders in digital environment. Section 1201 of DMCA implements the obligation to provide adequate and effective protection against circumvention of technological measures used by copyright owners to protect their works.

Section 1201 divides technological measures into two categories: measures that prevent unauthorized access to a copyrighted work and measures that prevent "Copying" is used in this context as a short-hand for the exercise of any of the exclusive rights of an author under section 106 of the Copyright Act (Copyright Summary.1998). However, some scholars argues that even though the DMCA have enhanced the ability of copyright owners to wield electronic protective measures to control new kinds of exploitations, the goal of copyright law should not be control over works of authorship (Ginsburg, 2001).

Furthermore, there are six additional exceptions mandated in the DMCA to strike down a balance between the interests of the owners and general public namely, non-profit library, achieve and educational institution exception, reverse engineering, encryption research, protection of minors, personal privacy, and security testing. Thus, it can be argued that the USA experience is well complied with the international standards.

As well, the European Union Copyright Directive (EUCD), the Directive on the harmonization of certain aspects of copyright and related rights in the information society also contains a number of prescriptive non-mandatory exceptions which national governments may include in their EUCD implementation legislation if they so wish. It includes exceptions such as temporary reproductions, photographic reproduction of copyright materials, private use and etc. However, the real application and effectiveness of these expanding limitations, scope and protection relating to copyrights and related rights in a digital environment is notably controversial.

\section{Liability on copyright infringement in digital environment: Examples from case law}

When examine the US case law, it can be found series of cases which have extensively discussed the nature of liability on copyright infringement in the digital environment. Particularly, in Sony $v$ Universal Studios (1984), also known as the Betamax decision, the US Supreme Court considered whether Sony is liable for manufacturing and marketing home- use video cassette recorders (VCR). After concerning the competent interests of copyright holders and others who are involved in commercial enterprises, the Court held that, there was no contributory copyright infringement where the product is 'capable of substantial' or 'commercially significant noninfringing uses'.

Furthermore, in Metro-Goldwyn-Mayer Studios v Grokster Inc. (2005), also dealt with the issue of indirect or contributory liability. In this case, entertainment companies sued the manufacturers of file-sharing software that allows computer users to download music and movies from each 
B.A.R.R Ariyaratna, W.A. Sanath Sameera Wijesinghe, 2018, Vol.2, Issue.2, pp.44-55

other's computers. It was argued that such downloads violate copyright protections and amount to stealing. However, the Court was mindful of the balance between supporting creativity through copyright protection and promoting the innovation of technology by limiting copyright infringement liability (Dimock and Punniyamoorthy, 2006) and held that,

“...distributors of P2P sharing software may be liable for inducing copyright infringement even if the software is capable of substantial non-infringing uses. Infringement is possible when a device is distributed with the object of promoting its use to infringe copyright, as shown by clear expression or other affirmative steps taken to foster infringement".

As well, in AEM Recording v. Napster Inc. (2001) case the US Court held that, Napster was liable for contributory or vicarious copyright violations because it was allowing millions of users to download music for free. The same approach can be seen in the New York Times Co $v$ Tasini (2001). In Tasini, the majority of the US Supreme Court held that electronic databases and CDROMs are not simply 'revisions' of periodicals, and therefore explicit permission was required from the authors. The databases were found to infringe the freelance author's right to determine the individual reproduction and distribution of his literary work. (Dimock and Punniyamoorthy, 2006)

Warner Brothers and J.K Rowling v. RDR Books (2008) case is another prominent example which imposed liabilities on copyright infringements. In this case the Court issued a permanent injunction to prevent the RDR Books Co. from print-publishing the online guide created by Steve Vander Ark.

According to aforementioned case law it can be argued that the court has tended to impose indirect or vicarious or secondary or contributory liability on the part of service providers and hosts to protect the copyright owner's right in digital environment. However, the issue is, if the liability is imposed on the every issue, how it impacts on protecting and promoting freedom of expression and information.

\section{Striking a balance}

Even though, digitalization has created the greatest challenge to the copyright law, the law itself cannot restrict the advantages of digitalization for the boarder community perspective. As Dimock and Punniyamoorthy (2006) correctly pointed out, as a result of the digitalization,

"Creators want to ensure that their rights to the work they produce is protected and that others do not appropriate any benefits generated from it. In contrast, users such as teachers, researchers, students, internet service providers (ISPs) seek to ensure that restrictive copyright laws do not inhibit a free and fruitful exchange of digital information."

The Universal Declaration of Human Rights (UDHR) also emphasizes the need for balancing these competent interests. According to the Article 27(2) of the UDHR, "Everyone has the right to the protection of the moral and material interests resulting from any scientific, literary or artistic production of which he is the author." On the other, Article 27(1) connotes the right of general public as "Everyone has the right freely to participate in the cultural life of the community, to enjoy the arts and to share in scientific advancement and its benefits".

When examine the copyright law in relating to digital environment issues, court also emphasize the importance of harmonizing users and creators rights in the digital environment. It is evident 
B.A.R.R Ariyaratna, W.A. Sanath Sameera Wijesinghe, 2018, Vol.2, Issue.2, pp.44-55

that in Sony $v$ Universal Studios case the US court has taken a balanced approach to decide the competent interests of copyright holders and others who are involved in commercial enterprises.

As well, in many instances, the court applies fair use doctrine to strike a balance. As mentioned earlier, the acts of fair use include the use of a work for the purposes such as criticism, comment, news reporting, teaching, scholarship or research (Karunarathna,2010). In Kelly $v$ Arriba Soft Corp (2002) US Court of Appeals affirmed that unauthorized linking to thumbnail images was a non-infringing fair use. On the other hand, US court in Universal City Studios, Inc. v. Reimerdes (2000) case, dismissed the fact that there might be legitimate fair use reason for copying all the part of a DVD film using a software device.

Accordingly, it is noteworthy to point out that, the copyright protection in digital environment must encompass a fair balance between copyright holder's right and user's rights.

\section{Sri Lankan Experience}

The Sri Lankan IP law does not provide any specific protection for the copyright infringements in digital environment. However, according to the Section 9(1) of the Intellectual Property Act No. 36 of 2003 (the Act) in Sri Lanka, owner of copyright of a work shall have the exclusive right to carry out or to authorize the following acts in relation to the work, such as reproduction, translation, adaptation, public distribution and etc...

On the other, Section 11(1) of the Act spell out the fair use doctrine as, "the fair use of a work, including such use by reproduction in copies or by any other means specified by that section, for purposes such as criticism, comment, news reporting, teaching (including multiple copies for classroom use), scholarship or research, shall not be an infringement of copyright".

However, the notable fact is that, the Act imposes both civil and criminal liability for infringement of copyright and related rights. Section 170 of the Act allows the court to grant an injunction restraining copyright violations. As well, Section 178 states that any person who willfully infringes any of the rights protected under Part II of the Act shall be guilty of an offence and shall be liable on conviction after trial before a Magistrate.

In Hudson Samarasinghe v. Upali Sincoba Enterprises (2001) case Commercial High Court issued an interim injunction restraining the live performance of a song and producing, marketing and distribution of CDs and cassette named "Rangahala Gee 16" on the basis that the copyright over the lyrics of the song was with the plaintiff.

According to above legislative provisions and judicial interpretations it can be argued that though there is no express provision or law in Sri Lanka which specifically deals with copyright protection in digital environment, the existing IP legal framework could be used to address some issues arise in the digital platform.

\section{Some Possible Solutions}

After unveiling the existing problems on copy rights and related rights it is worthwhile to consider the possible solutions to overcome these obstacles. Accordingly, the following steps can be considered: 
1. Protection of technological measures such as conditional access systems and encryption which limit the access, as well as unauthorized copying and reproduction of copyrighted and related rights works.

2. Providing automated monitoring and registration of the works in respect of management of copyrights and related rights in a digital environment. This can be used as an assurance to the owners to find a record of every request and utilization of their works transmitted over the network.

3. Protecting the rights of the owners of copyrights and related rights by monitoring the conduct of service providers.

4. Defining the jurisdiction of the law suits on the infringements of copyrights and related rights in a digital environment. This would immensely help to obtain a speedy and cost effective remedy in the infringement of copyrights and related rights.

Furthermore, it can be suggested to initiate collective management system of copyrights and related rights which are specifically aimed to mitigate the violations and infringements of those rights in a digital environment. Thereby, the collective management organizations would serve as links between rights owners and users. Nonetheless, the owners of copyrights and related rights can get the assistance of these collective management organizations to enforce their rights.

When analysing the existing legal framework, it is clear that the remedies available in Section 170 of the IP Act of Sri Lanka, are not pervasive enough to provide effective damages for all kind of infringements occurred in digitalized environment. Nonetheless, it is worthwhile to explore the possibilities of introducing indirect or vicarious or secondary or contributory liability for the producers of modernize digital devices which can easily be used to infringe copyrights and related rights in digital era.

Thus, the existing legal framework should be re-envisaged by considering more sophisticated legal frameworks such as DMCA in US and the Australian Copyright Amendment (Digital Agenda) Act 2000 which is pervasive to cater to all issues which arises in a networked and digital environment. The above suggestions also can be considered while developing a comprehensive legal framework in the Sri Lankan context.

Particularly, the liability on internet service providers include, Google, ebay and etc. should be subjected to certain guidelines and principles (Copyright News, 2012). Therefore, another contentious issue might be arising, whether, the provisions of IP Act wide enough to cover the service providers' infringement? Accordingly, it can be argued that, as one option the provisions of the IP Act could be expanded to cover that kind of situations. Secondly, the provisions of Computer Crime Act No 24 of 2007 can be considered to apply imposing the liability for this kind of situation

\section{Conclusion}

As Rafiqi and Bhatt (2013) correctly opined, the puzzles and paradoxes underlying the digital dilemma, by nature are connected with the dichotomy between the notion of 'information wants to be free' and the demands for stronger proprietary control of information in the digital environment. Accordingly, it is evident that there are plethora of complicated issues to be addressed in copyright and related rights law which arise as a result of modern digitalization. 
B.A.R.R Ariyaratna, W.A. Sanath Sameera Wijesinghe, 2018, Vol.2, Issue.2, pp.44-55

Therefore, as mentioned, on the one hand strong legal mechanism is essential to ensure that authors and artists are safeguard against commercial exploitation. On the other hand, there should be serious consideration that any change in policy or law should not restrict the reasonable use of digital advancement.

\section{References}

\section{Books}

Bently, L \& Sherman, B. (2004) Intellectual Property Law, Oxford University Press.

Fisher, W. (2001), Theories of Intellectual Property: New Essays in the Legal and political theory of property, Cambridge University Press.

Karunarathne, D.M. (2010) Elements of the Law of Intellectual Property in Sri Lanka, Sarasavi Publishers.

WIPO, 2008, Intellectual Property Hand Book, WIPO Publications.

\section{Journal Articles}

Dimock R.E \& Punniyamoorthy,S .(2006). Digital technology: its impact on copyright law and Practice in North America, Journal of Intellectual Property Law and Practice.

Fleischmann, E. (1987) The Impact of Digital Technology in Copyright Law, The John Marshall Journal of Information Technology and Privacy Law, Vol 8

Ginsburg, J.C. (2001) Copyright and Control over new Technologies of Dissemination, Colombia Law Review, Vol.101

Rafiqi, F.H \& Bhat., I.H . (2013) Copyright Protection in Digital Environment: Emerging Issue, International Journal of Humanities and Social Sciences Invention, Vol 2.

\section{Web Sources}

A Guide to copyright Organization of Trinidad and Tobago', http://www.cott.org.tt/ accessed on 05 October 2016

Copyright Office, (1998), Unauthorized copying of a copyrighted work, Copyright Office Summary, Retrieved from https://www.copyright.gov /legislation/dmca.pdf, Accessed on 2.11.2016

IFLA, (2004), Limitations and Expectations of Copyrights and Neighboring Rights in the Digital Environment: An International Library Perspective, Retrieved from $<$ http://www.ifla.org/publications/limitations-and-exceptions-to-copyright-and-neighbouringrights-in-the-digital-environm> accessed 11 October 2016

Kenya Copyright Board, (2012) Copyright in the Digital Environment', Copyright News (issue 5) Retrieved from file:///C:/Users/Dell/ Desktop/LLM/IP\%0LAW/IP\%20Term\%202/attachments\%20(2)/issue5.pdf, accessed 11 October 2016

Sarraco, C. Intellectual Capital in the Information Society, Retrieved from $<$ http://www.itu.int/osg/spu/visions/free/ITUIntCapitalpaper.pdf>, accessed 10 October 2016

\section{International Conventions and Treaties}


B.A.R.R Ariyaratna, W.A. Sanath Sameera Wijesinghe, 2018, Vol.2, Issue.2, pp.44-55 Berne convention of 1971

European Union Copyright Directive (Directive 2001/29/EC)

Universal Declaration of Human Rights

WIPO Copyright Treaty of 1996

WIPO performances and Phonograms Treaty

\section{Legislations}

Australian Copyright Amendment (Digital Agenda) Act 2000

Computer Crime Act No 24 of 2007

Intellectual Property Act No 36 of 2003 in Sri Lanka

US Digital Millennium Copyright Act

\section{Case Law}

Sony Corp of America v Universal City Studios, Inc , 464 US 417, 774 (1984).

Metro-Goldwyn-Mayer Studios v Grokster Inc (545 US 913 (2005))

AEM Recording v. Napster Inc (239 F.3d 1004 (2001))

New York Times Co v Tasini, 533 US 483 (2001)

Warner Brothers and J.K Rowling v. RDR Books (575 F.Su.2n 513 (SDNY 2008))

Kelly v Arriba Soft Corp , 280 F.3d 934 (9th Cir 2002)

Universal City Studios, Inc. v. Reimerdes, 111 F. Supp.2d 294 (SDNY 2000)

Hudson Samarasinghe v. Upali Sincoba Enterprises (2001) unreported 